\title{
Determination of Anti-Nuclear Antibody Seroprevalence in Adult Age Groups in Trabzon Province
}

Anti-nuclear antibody (ANA) is the general name given to antibodies developing against deoxyribonucleic acid-histone complexesortonuclearand cytoplasmicribonuclearproteins(1). Investigation of ANA seroprevalences is important, not only in the identification of autoimmune diseases in societies, but also in revealing subclinical conditions prior to disease, guiding early treatment and monitoring and in establishing the risk factors for these diseases (2). ANA seroprevalences between $4.2 \%$ and $22.6 \%$ have been reported for different societies (3-9). However, there are insufficient data regarding the ANA seroprevalence for the Eastern Black Sea region of Turkey, which includes the province of Trabzon, as well as for other regions of the country. Our study therefore intended to determine ANA seroprevalence in the adult age group population in Trabzon and to investigate the relationship between the presence of these antibodies and individuals' sociodemographic characteristics.

Serum specimens were collected from individuals aged 20 or above, living in nine separate districts, taking into account the geographical characteristics of the Trabzon provincial centre and outlying area; these were chosen at random between August 2007 and August 2008. On the prediction that the highest prevalence would be $15 \%$ and using the formula $n=Z^{2}{ }_{1-\alpha / 2} /\left[p(1-p) / d^{2}\right]$ with a $99 \%$ confidence interval and $3 \%$ deviation, a sample size of 884 was calculated. The age, gender, place of residence, cigarette smoking status and body mass index (BMI) of the individuals included in the study were determined. Approval for the study was obtained from the Karadeniz Technical University Faculty of Medicine Local Ethical Committee (meeting no: 2011/27, decision no: 2).

Four hundred and fifty-three (51.24\%) subjects were female and 431 (48.76\%) male. Antibodies against cell nuclei (lgG) (Euroimmun, Lübeck, Germany) kits were used in order to detect ANA in specimens. Sera were diluted to 1:80 and incubated with HEp-2 cells for $30 \mathrm{~min}$ at room temperature (RT). After washing with wash buffer (WB; phosphate buffer solution and Tween), the slides were incubated for $30 \mathrm{~min}$ with goat anti-human lgG conjugated with fluorescein isothiocyanate. After a second wash with PBS-Tween solution and embedding with mounting medium, the slides were examined under an immunofluorescence microscope (Euroimmun, Lübeck, Germany).

ANA positivity and staining patterns were determined by two separate individuals, and the results were evaluated as $1+(1: 80), 2+(1: 160), 3+(1: 320)$ or $4+(1: 640)$. The presence of extractable nuclear antigen (anti-ENA) antibodies in speci- mens exhibiting a speckled staining pattern was investigated using Anti-ENA Profile Plus1 (lgG) (Euroimmun, Lübeck, Germany) kits. Patient sera were diluted 1:100 in sample buffer. Each nitrocellulose strip containing SSA, SSB, Sm, nRNP/Sm, $\mathrm{Scl}-70$, Jo-1, and serum control (anti-human lgG) was placed in a channel of the incubation tray and incubated with $1.5 \mathrm{ml}$ sample buffer for $5 \mathrm{~min}$ at RT. After aspiration of the liquid, $1.5 \mathrm{~mL}$ diluted samples were added and incubated for $30 \mathrm{~min}$ at RT. After washing three times with $\mathrm{WB}, 1.5 \mathrm{~mL}$ enzyme conjugate (alkaline phosphatase-labelled anti-human lgG) was added to each channel and incubated for $30 \mathrm{~min}$ at RT. After a second wash, $1.5 \mathrm{~mL}$ substrate solution was added and incubated at RT for a further $10 \mathrm{~min}$. Finally, $1.5 \mathrm{~mL}$ stop solution was added following three washes. The strips were evaluated using the EUROLineScan program (Euroimmun, Lubeck, Germany).

Descriptive data are presented as number and percentages. The data obtained were compared using the chi-square test.

Anti-nuclear antibody seropositivity at a titre of 1:80 was determined in 132 (14.93\%) specimens. Positivity at titres of $1: 160$ and above was seen in $48(5.43 \%)$ specimens. Speckled staining was the most frequent pattern, which was seen in $53(6.00 \%)$ specimens. Thirty-five $(4.00 \%)$ of these were fine speckled, $5(0.57 \%)$ coarse speckled and $13(1.47 \%)$ homogeneous and speckled. A cytoplasmic pattern was determined in $36(4.07 \%)$ specimens, a nucleolar pattern in 26 (2.94\%) and a homogeneous pattern in 5 (2.03\%). Mid-body was identified in $5(0.56 \%)$ specimens, nuclear dot in $3(0.33 \%)$, centromere in $2(0.22 \%)$, and spindle fibres in $1(0.11 \%)$. The most frequently determined anti-ENA antibody was Ro52 (2.6\%). Positivity levels of $2.14 \%$ for SS-A, $1.58 \%$ for Sm, $1.24 \%$ for SS-B and Scl-70, 1.01\% for nRNP/Sm and $0.90 \%$ for Jo- 1 were determined.

Anti-nuclear antibody positivity was detected in 73 (16.11\%) of the women in the study and 59 (13.68\%) of the men. The highest positivity was determined in the 30-39 years age group (16.25\%) and the lowest at age 70 and above $(12.72 \%)$. ANA seropositivity was identified in $14.97 \%$ of subjects living in the provincial centre, $14.86 \%$ of those living in outlying districts, $11.36 \%$ of smokers, $16.34 \%$ of nonsmokers, $16.30 \%$ of former smokers, $13.04 \%$ of individuals with a BMI above 25 and $14.98 \%$ of those with a BMI below 25 . No statistically significant correlation was determined between ANA seropositivity and gender, age, place of residence, cigarette use or BMI $(p=0.312, p=0.980, p=0.987, p=0.054$ and $p=1.000$, respectively). 
Ours is the first study to investigate ANA seroprevalence in a broad study group in the Turkish population. The seroprevalence in our province was $14.93 \%$ at a $1: 80$ titre, and $5.43 \%$ at titres of 1:160 or above. This is a similar level to that of ANA seropositivity in several countries (Mexico - 13.4\% at a titre of $1: 40$ and $3.2 \%$ at $1: 160$ titre; Belgium - $13.0 \%$ at a titre of 1:80; USA $-13.8 \%$ at $1: 80$ titre; Japan $-20.0 \%$ at a titre of $1: 40$ and $9.5 \%$ at a titre of $1: 160)(3,4,8,9)$. This study used sera collected in order to determine the seroprevalence of HSV-2 in the community (10). Clinical signs and symptoms of autoimmune diseases could not, therefore, be evaluated. This represents the limitation of the study. No significant difference was determined between sociodemographic characteristics in terms of ANA seropositivity. We therefore believe that ANA screening tests should be performed in all patients whose clinical findings suggest autoimmune diseases.

\section{Neşe Kaklıkkaya', Altan Akıneden' ${ }^{1}$, Murat Topbaş², Faruk Aydın ${ }^{1}$ \\ ${ }^{1}$ Department of Medical Microbiology, Karadeniz Technical University Medical Faculty, Trabzon, Turkey \\ ${ }^{2}$ Department of Public Health, Karadeniz Technical University Medical Faculty, Trabzon, Turkey}

Ethics Committee Approval: Ethics committee approval for the study was obtained from the Karadeniz Technical University Faculty of Medicine Local Ethical Committee (meeting no: 2011/27, decision no: 2).

Informed Consent: Informed consent was obtained from the participants of the study.

Peer-review: Externally peer-reviewed.

Author contributions: Concept - N.K.; Design - N.K.; Supervision F.A., M.T.; Resource - N.K., A.A.; Materials - M.T.; Data Collection\&/or Processing - N.K., A.A., M.T.; Analysis\&/or Interpretation - M.T.; Literature Search - N.K., A.A.; Writing - N.K.; Critical Reviews - M.T., F.A.

Conflict of Interest: No conflict of interest was declared by the authors.

Financial Disclosure: This study was supported by Karadeniz Technical University Scientific Research Projects Coordination Unit.

\section{References}

1. Kumar $Y$, Bhatia A, Minz RW. Antinuclear antibodies and their detection methods in diagnosis of connective tissue diseases: a journey revisited. Diagn Pathol 2009;4:1. [CrossRef]

2. Pisetsky DS. Antinuclear antibodies in healthy people: the tip of autoimmunity's iceberg? Arthritis Res Ther 2011;13:109-10. [CrossRef]

3. Marin GG, Cardiel MH, Cornejo H, Viveros ME. Prevalence of antinuclear antibodies in 3 groups of healthy individuals: blood donors, hospital personnel, and relatives of patients with autoimmune diseases. J Clin Rheumatol 2009;15:325-9. [CrossRef]

4. de Vlam K, De Keyser F, Verbruggen G, Vandenbossche M, Vanneuville $B, D^{\prime}$ Haese $D$, et al. Detection and identification of antinuclear autoantibodies in the serum of normal blood donors. Clin Exp Rheumatol 1993;11:393-7.

5. Vazquez-Del Mercado M, Gonzalez-Bernaldez M, Garcia-De La Torre I. Prevalence of antinuclear antibodies in a Huichol population of Mexico. Lupus 1995;4:164-5. [CrossRef]

6. Fernandez SA, Lobo AZ, Oliveira ZN, Fukumori LM, $P$ rigo AM, Rivitti EA. Prevalence of antinuclear autoantibodies in the serum of normal blood donors. Rev Hosp Clín Fac Med S Paulo 2003;58:315-9. [CrossRef]

7. Al Jabri AA, Al Belushi MS, Nsanze H. Frequency and levels of otoantibodies in healthy adult Omanis. Ann Saudi Med 2003;23:372-5.

8. Satoh M, Chan EK, Ho LA, Rose KM, Parks CG, Cohn RD, et al. Prevalence and sociodemographic correlates of antinuclear antibodies in the United States. Arthritis Rheum 2012;64:2319-27. [CrossRef]

9. Hayashi N, Koshiba M, Nishimura K, Sugiyama D, Nakamura T, Morinobu S, et al. Prevalence of disease-specific antinuclear antibodies in general population: estimates from annual physical examinations of residents of a small town over a 5 -year period. Mod Rheumatol 2008;18:153-60. [CrossRef]

10. Topbas M, Can E, Kaklikkaya N, et al. Herpes Simplex-2 seroprevalence among adults aged $20-49$ in Trabzon. Nobel Med 2012;8:85-90. 